Review Article

\title{
Recent Hydrogeological Research in India
}

\author{
DIPANKAR SAHA ${ }^{1}$, SHASHANK SHEKHAR ${ }^{2}$, SHAKIR ALI $^{2, *}, \mathrm{~S} \mathrm{~S} \mathrm{VITTALA}^{1}$ and N J RAJU 3 \\ ${ }^{1}$ Central Ground Water Board, MOWR, RD \& GR Government of India \\ ${ }^{2}$ Department of Geology, University of Delhi, Delhi 110 007, India \\ ${ }^{3}$ School of Environmental Sciences, Jawaharlal Nehru University, New Delhi 110 067, India
}

(Received on 10 June 2016; Accepted on 15 June 2016)

\begin{abstract}
The hydrogeological setup of India represents a wide variation, from rugged Himalayan mountainous region in the north, extensive Indo-Ganga-Brahmaputra floodplain and deltaic region in the central and eastern part, aeolian- alluvial deposits in the west, vast basalt flows in the west central part, gently undulating central and southern region underlain by Precambrian crystalline, sedimentary and metamorphic, coastal deposits along the east coast etc.

The research on hydrogeology has got special socioeconomic significance because India is now the largest extractor of groundwater in the world. The impact of overexploitation of the resource is surfacing in large parts of the country, in the form of lowering of water level, dwindling yield of well and deterioration in water quality.

In recent years, extensive studies have been carried out in this field of geoscience. We have discussed these in different segments, after enumerating the broad hydrological framework of India. The segments are 1. Hydrogeological investigations in Indo-Ganga-Brahmaputra Plains holding one of the potential aquifer systems 2. Groundwater chemistry and contamination issues in Peninsular India 3. Urban hydrogeology 4. Groundwater modeling 5. Ground water exploration 6. Groundwater recharge and associated quality issues 7. Remote sensing and GIS applications 8. Coastal aquifers and 9. Groundwater management.

It is observed that the potential groundwater reserve in the Indo-Gangetic basin and the Peninsular part of India has two serious issues: 1. Overexploitation of groundwater mainly in the western and north western parts and also in southern peninsular India in pockets and 2. Groundwater quality deterioration by anomalous concentration of arsenic, fluoride and salinity. The findings of the research will help in understanding the hydrogeological complexities in its entire gamut and also offers insight into the ways for sustainable management of groundwater resource of the country.
\end{abstract}

Keywords: India, Hydrogeology; Groundwater Extraction; Indo-Gangetic Plain; Groundwater Quality; Fluoride; Arsenic; Groundwater Pollution; Groundwater Modeling

\section{Introduction}

India, spanning over approximately 3.2 million $\mathrm{km}^{2}$, exhibits wide variety of rock types, ranging from Recent deposits along the flood plain of river, air borne sediments in arid areas and the extensive coastal deposits, to some of the oldest igneous and metamorphic suite of rocks of the world. In accordance with the wide range of rock types, there is wide variation in hydrogeological settings, groundwater occurrence, flow regime and a wide variety of rock-water interaction in the country.

\footnotetext{
*Author for Correspondence: E-mail: shakiriitb@gmail.com
}

\section{Aquifer Systems in India}

The country is broadly divided into different segments depicting different hydrogeological framework. Central Ground Water Board (CGWB, 2014) has identified fourteen principal aquifers systems in India (Fig. 1). A brief description of the principal aquifer systems is given below.

\section{Alluvial Aquifers}

The Quaternary sediments comprising Recent Alluvium, Older Alluvium, Aeolian and coastal deposits 


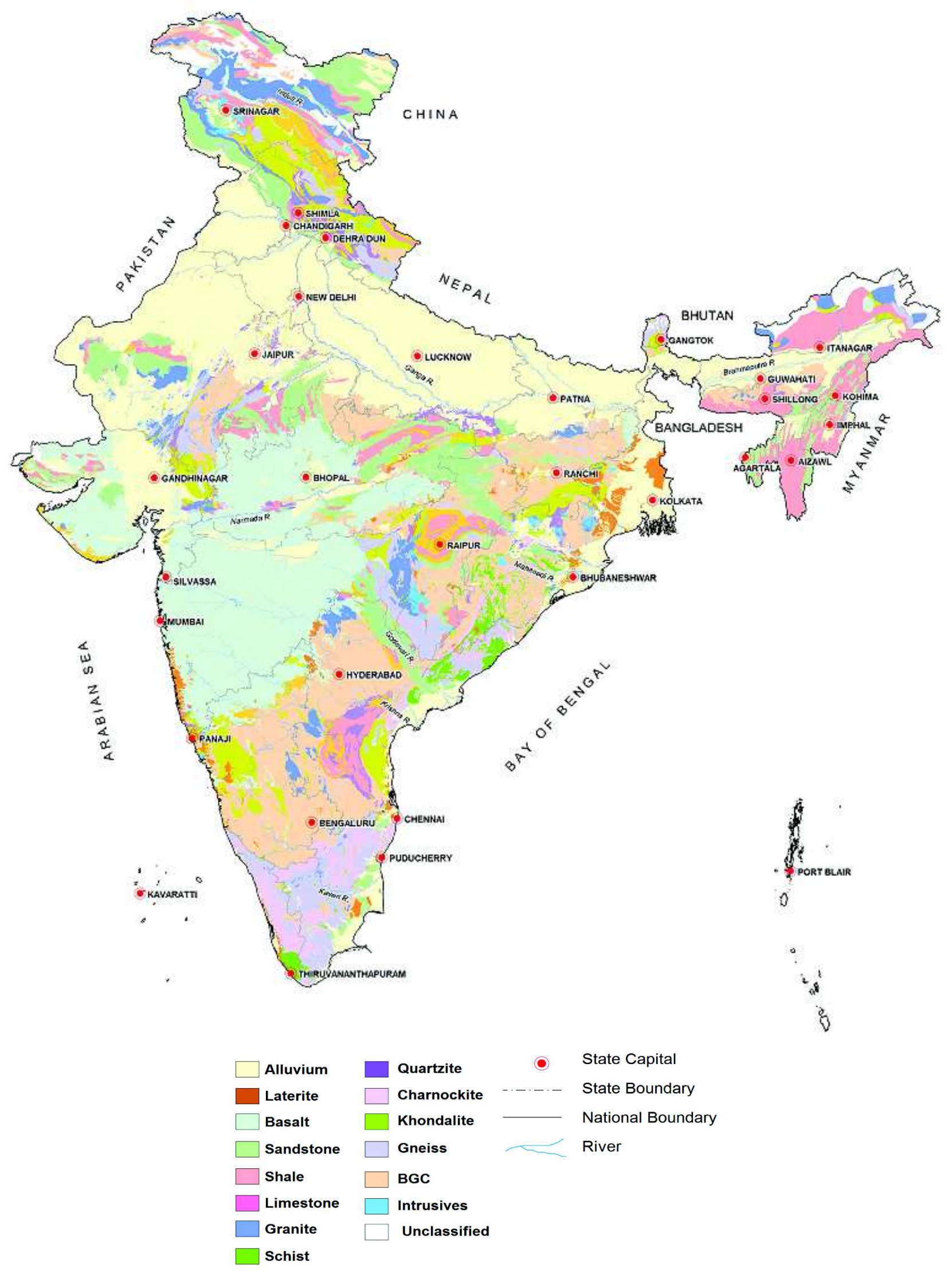

Fig. 1: Principal aquifer systems of India (adopted from CGWB 2014) 
are clubbed into this group. The sediments are essentially composed of clay, silt, sand, pebble and kankar and hold potential groundwater reservoirs for extensive development. The Indo-GangaBrahmaputra Plains represent a thick unconsolidated aquifer system, holds enormous groundwater reserve. In many parts, these aquifer systems are bestowed with high incidence of rainfall; thus get significant annual recharge rendering them excellent source for drinking and irrigation. In addition to the annual recharge from rainfall, there exists a huge groundwater reserve in the deeper passive recharge zone as well as in the deeper confined aquifers which extend even beyond $600 \mathrm{~m}$ below ground level (bgl) or so, which has largely remained unexplored. The unconsolidated aquifers along the coast are equally productive but show wide variation in the water quality, both spatially and vertically, thus imposing quality constraint for groundwater development. The groundwater prospect of the Aeolian deposits is constrained by deep water level, over exploitation and salinity hazard.

\section{Laterite}

Laterites are formed by the leaching such as chemical weathering of wide spectrum of rocks, ranging from sedimentary, metamorphic and crystalline types. Laterites are extensively developed aquifers in the Indian peninsular states. They form potential aquifers along valleys and topographic lows where the thickness of the saturated zone is more and can support large diameter open wells and much beneficial for domestic and irrigation purposes.

\section{Sandstone and Shale}

The aquifers belong to this group range in age from Carboniferous to Mio-Pliocene. The Gondwana System and the Tertiary deposits along east coast, like Cuddalore sandstone, in western part of India like Lathis as well as in the north-east like Tipam and their equivalents are most productive aquifers.

\section{Carbonate Rocks}

The consolidated carbonate rocks such as limestone, dolomite and marble fall in this group. Among those limestone is the most predominant and productive from groundwater prospect view. The fractured zone and solution cavities constitute the most potential aquifer zones.

\section{Basalt Flows}

The Deccan Traps made up of stratified basalt flows, covers about 1.5 million $\mathrm{km}^{2}$ areas, spread largely over the states of Maharashtra and also in parts of Madhya Pradesh, Gujarat and Karnataka. Besides, small patches of basalt flows are also observed in other state like in Jharkhand.

Groundwater occurrence and movement in basalt flows is controlled by nature, thickness and extent of weathering, presence of vesicular zones in individual flows, the fractures as well as the nature of intertrappen layers. These aquifers generally have medium to low permeability. Contrasting water bearing properties of lower massive and upper vesicular parts in a flow unit sometime result in multiple aquifer system as number of flows are stacked in an area.

\section{Crystalline Hard Rock Aquifers}

Granite, gneisse and the suite of metamorphic rocks including khondalites and charnockites as well as consolidated Precambrian sedimentaries such as Vindhyan and its equivalents fall under this category. Weathered zone and the underline fracture system form good aquifers. The fracture system in these aquifers includes fractures; joints, bedding planes etc. and they are encountered even beyond $400 \mathrm{mbgl}$. The fractures when densely zoned and interconnected forms potential aquifer. But generally the fractures are anisotropically distributed and targeting groundwater poses a challenge. The weathered zone thickness generally varies from 10 to $30 \mathrm{~m}$ and holds some groundwater potential and developed through dug wells.

\section{Research in Hydrogeology}

Significant works are going on in this domain on wide ranging subjects, from aquifer characterization, targeting potential aquifer, rock-water interaction, groundwater contamination, recharging aquifers and use of state of the art tools. The researches carried out in the last five-six years have been captured and grouped in nine categories as below.

\section{Hydrogeological Investigations in Indo-Ganga- Brahamputra Plains}

Indo-Gangetic Plains in India is experiencing one of the most intensive groundwater extractions in the 
world; mainly because of spiral rise in the demand from the irrigation sector (Mukherjee et al., 2015a). The sediment in the basin was deposited by past and present day rivers from the Himalaya and cratonic provinces (Sinha et al., 2009; Singh, 1996). The Plains form large aquifer system and at places the aquifers are trans boundary in nature, between the states, IndiaNepal, India-Pakistan and India-Bangladesh. Efforts have been made to correlate the aquifer geometry and their disposition in relation to geomorphology and neotectonic activity (Sahu and Saha, 2014a; Sahu et $a l ., 2010)$. The younger alluvium in the flood plain of the present day rivers has high ground water potential (Shekhar et al., 2015; Shekhar and Prasad, 2009). The rainfall in the basin varies from less than $25 \mathrm{~mm}$ per annum in southern Pakistan to greater than 2000 $\mathrm{mm}$ in the Bengal basin (MacDonald et al., 2015).

The depth of groundwater level shows wide spatial variation in the Plains. In Brahmaputra plains as well as in West Bengal, Bihar, eastern and central parts of Uttar Pradesh, the water level by and large remains within $20 \mathrm{~m}$ below ground. But in the western part like in Haryana, Punjab and Rajasthan, the water levels recede even beyond $60 \mathrm{mbgl}$. Punjab and Haryana states also experience highest rate of groundwater abstraction in the world (Van Dijk et al., 2016)

The total groundwater abstraction from the Indo Gangetic basin is about $205 \mathrm{~m}^{3}$, which amounts to 20 $25 \%$ of total global groundwater abstraction (MacDonald et al., 2015). In recent years the groundwater level decline linked to over-exploitation, have been mostly noticed in aquifers of Indo-Gangetic Plains, occupying north-western states of India like Punjab, Haryana, Rajasthan and Delhi (Sarkar et al., 2016; MacDonald et al., 2015; Dasgupta et al., 2014; Saha et al., 2010; Tiwari et al., 2009; Rodell et al., 2009; Chatterjee et al., 2009). More than $80 \%$ of the groundwater abstraction is for agriculture. However, localized high abstraction is also observed in urban areas leading to continuous decline of water level. Saha et al. (2013) and Dwivedi and Singh (2015) studied the aquifer system and groundwater extraction in Patna urban area, located in the Middle Gangetic Plains. Sinha et al. (2013) investigated paleo-channels, which often contain potential aquifers, through resistivity survey. Bawa et al. (2014) established that excessive groundwater withdrawal in middle reaches of Yamuna basin has affected river flow.

Groundwater quality issues of the Indo-GangaBrahmaputra Plains as well as the entire basin area have been investigated in detail. In the Indo-Gangetic Plains, groundwater quality shows wide spatial variation (Sarkar and Shekhar, 2015; Sarkar and Shekhar, 2013). Arsenic contamination (Saha and Sahu, 2016; Kumar et al., 2016; Jangle et al., 2016; Chakraborti et al., 2016; Alam et al., 2016; Shah, 2015; Mukherjee et al., 2015a; Singh et al., 2014; Sahu and Saha, 2014b; Saha and Shukla, 2013; Shah, 2013; Singh et al., 2013a; Raju, 2012a, 2012b; Mukherjee et al., 2012a; Dubey et al., 2012; Saha et al., 2011; Mukherjee et al., 2011e; Kumar et al., 2010; Shah, 2010; Saha, 2009; Saha et al., 2009) and elevated concentration of fluoride (Ali et al., 2016; Sarkar and Shekhar, 2015; Shekhar and Sarkar, 2013; Raju et al., 2009; Saxena and Ahmed, 2003) in groundwater along with salinity has been identified as the major quality issue (Shekhar et al., 2015).

The Indo-Ganga-Brahamputra Plains has attracted the attention of researchers for arsenic contamination of groundwater (Banerjee et al., 2012) as evident from large number of research works mentioned above. Though, it was reported about three decades before in West Bengal (Garai et al. 1984) from the upstream of Garo-Rajmahal Gap, the initial report was made in 2003 (Chakraborti et al., 2003). These findings kick; started researches and various departmental investigations in Middle and Upper Ganga Plains as well as in the Brahmaputra valley.

Saha (2009) had compiled an overview of extent of arsenic contamination, its geographical distribution in the state of Bihar. The mobilization process of arsenic and hydrogeochemical evolution of groundwater has been studied in details in different contaminated pockets (Saha et al., 2009; Chauhan et al., 2009; Mukherjee et al., 2015a; Shah 2015; Kumar et al., 2010; Mukherjee et al., 2011e; Raju, 2012a). The arsenic contaminated areas are confined along the Holocene deposits and reported both from the Younger and Older Flood Plain, while the Pleistocene deposits are found to be free from contamination (Sahu and Saha, 2014b; Pandey et al., 2015). Raju (2012a) studied the hydrogeochemistry of groundwater in Pleistocene deposits. The contaminants areas are underlain by multi aquifer system made up of 
Quaternary deposits. Investigation revealed arsenicfree deeper aquifer and their hydraulic separation from the shallow contaminated aquifers (Saha and Shukla, 2013; Saha et al., 2010). At places in West Bengal, elevated concentration of arsenic is reported from deeper aquifer (Mukherjee et al., 2011e). Saha et al. (2013) applied isotopic techniques to understand the recharge mechanism and established that shallow contaminated aquifers get quick recharge from rainfall while the deeper aquifers represent older water having recharge area far off. Researchers also attempted vulnerability analyses and entry of arsenic in the food chain in parts of Middle Ganga Plain and its health impact (Singh and Ghosh, 2011; Singh et al., 2011). The fixation of arsenic in the cereal grown in the contaminated region focusing on Bengal delta plain have been discussed in details by Chatterjee et al. (2010), Halder et al. (2012) and Bhattacharya et al. (2010a and 2010b). They conclude that the consumption of groundwater and rice grown using contaminated water are the major pathways of arsenic in human bodies. Sankar et al. (2014) had studied geogenic arsenic and manganese contamination in four blocks on either side of the river Bhagirathi in Murshidabad district. Singh et al. (2013b) studied heavy metal concentration in groundwater of Satluj basin. Bhattacharya et al. (2010a) had studied in detail the arsenic concentration of different rice and vegetables varieties grown in the contaminated areas of West Bengal.

Interesting researches also carried out in various parts of north-east India viz., Barak valley, Brahmaputra Plains, Manipur state and north of Mizoram state on arsenic contamination (Chakraborty et al., 2008; Chetia et al., 2011; Buragohain et al., 2010; Oinam et al., 2012; Shah 2012; Kumar et al., 2013). In a significant work, Mahanta et al. (2015) studied arsenic enriched groundwater regime within Brahmaputra flood plains. These authors observed the origin, distribution and processes of arsenic release by investigating the groundwater chemistry and subsurface sedimentological characteristics.

Beside arsenic, fluoride and salinity contamination in the groundwater system is predominantly observed in arid and semiarid regions confined to western and north western parts (Singh and Mukherjee, 2014). Sporadic fluoride contamination has also been observed in eastern part of the Ganga basin. The deltaic area of West Bengal and Bangladesh also has aquifers bearing saline groundwater.

Ali et al. (2016) observed that high values of fluoride in groundwater are mainly confined to arid and semi-arid zones in the world as well as in India. Hussain et al. (2013) studied fluoride contamination in groundwater of 121 localities in Bhilwara district of Rajasthan. The groundwater from deep aquifers shows fluoride concentration in the range of 0.5 to $5.8 \mathrm{mg} / \mathrm{L}$. Based on the concentration of fluoride, these authors categorized the district into five categories.

Raju et al. (2012) studied fluoride hazard and assessment of groundwater quality in the semi-arid Upper Panda River basin, Sonbhadra district, Uttar Pradesh. Further, Raju (2016) studied the details about the genesis of fluoride in Padwakodari area of the same district. Singh et al. (2011) and Mukherjee et al. (2011d) studied groundwater quality of Pokhran area, Rajasthan. The process of fluoride enrichment in Thar desert was studied by Singh et al. (2012)

Sarkar and Shekhar (2015) studied hydrochemical facies and major ion variations in South West district of Delhi. They attributed this to geology as main geogenic source while heavy groundwater abstraction to be major anthropogenic source. Shekhar and Sarkar (2013) studied groundwater quality in the vicinity of Najafgarh drain in Delhi NCT. It was inferred from this study that anthropogenic contamination has much impact on the water quality in the vicinity of Najafgarh drain. The impact of landuse on groundwater quality has been also studied by Mukherjee et al. (2011b) and Srivastava et al. (2014)

In Uttar Pradesh, Singh et al. (2015) studied hydrochemistry of groundwater in parts of ChandauliVaranasi region where the domination of cations and anions was observed in the order of $\mathrm{Na}>\mathrm{Ca}>\mathrm{Mg}>$ $\mathrm{K}$ and $\mathrm{HCO}_{3}>\mathrm{Cl}>\mathrm{SO}_{4}>\mathrm{NO}_{3}>\mathrm{F}$. Alam and Umar (2013) in an exhaustive research discussed about the origin and distribution of trace element in Hindon Yamuna region in Upper Ganga Plain. The study reveals anthropogenic sources for the contamination. Further, Khan et al. (2010) studied trace elements in groundwater of western Uttar Pradesh. These authors observed high concentration of $\mathrm{Fe}, \mathrm{Mn}, \mathrm{Sr}, \mathrm{Cr}, \mathrm{Al}$ and $\mathrm{Pb}$ above than the permissible limit in the groundwater. These authors attributed this high value to the industrial 
effluents of sugar mills, pulp and paper factories and municipal waste in the area.

Raju et al. (2011) studied hydrogeochemical parameters for groundwater samples of the Varanasi, Uttar Pradesh. These authors observed high concentration of nitrate in about $18 \%$ of the groundwater samples and attributed this to local domestic sewage, leakage from septic tanks etc. In addition, high nitrate concentration has also been reported from other parts of the Gangetic Plains and attributed to the heavy dose of fertilizers used for agriculture. However, it has been observed that the deeper aquifers are less vulnerable from nitrate contamination (Saha and Alam, 2014).

Oinam et al. (2012) studied Imphal and Thoubal district of Manipur and observed that groundwater is predominanetly $\mathrm{Ca}-\mathrm{HCO}_{3}$ type and mixed $\mathrm{Ca}-\mathrm{Na}-$ $\mathrm{HCO}_{3}, \mathrm{Ca}-\mathrm{Mg}-\mathrm{Cl}$ type facies. Few samples also demonstrate $\mathrm{Na}-\mathrm{Cl}$ and $\mathrm{Ca}-\mathrm{Cl}$ type facies.

Shah and Umar (2015) used stable isotope content and deuterium excess in groundwater in parts of Unnao district in Uttar Pradesh, which indicates the single source of recharge in both pre and postmonsoon seasons. Investigation of the salinization of aquifers in Delhi has been attributed to various reasons by Kumar et al. (2015). Mukherjee (2015) discussed about impact of climate change on water quality variation.

Geology is the primary control on groundwater quality variation linked to geogenic sources (Sarkar and Shekhar, 2015; Shekhar and Sarkar, 2013; Sarkar and Shekhar, 2013), however, anthropogenic forcing has also left its distinct mark on groundwater quality in the basin.

\section{Groundwater Chemistry and Contamination Issues of Peninsular India}

Significant researches have been done on hydrogeochemical evaluation of groundwater emphasing on the mobilization and distribution of various contaminants such as fluoride, uranium and nitrate. In a study, Manikandan et al. (2014) investigated Krishnagiri district of Tamil Nadu and found that higher values of fluoride were associated with $\mathrm{Mg}-\mathrm{Na}-\mathrm{HCO}_{3}$ type facies. Further, they linked this to weathering of $\mathrm{Mg}$ bearing minerals such as biotite, hornblende and weathering of apatite/ hydroxyapaptites from the charnockites found in the region. The genesis and distribution of fluoride in Nalgonda district, Telangana state was discussed by Brindha et al. (2010). Besides fluoride, the nitrate is another issue of groundwater quality in the peninsular India. In same areas, Brindha et al. (2010) have discussed the nitrate pollution and related its origin to poor sanitation facility and indiscriminate dumping of municipal waste. Dar et al. (2011) observed fluoride concentration in the range from 1 to $3.24 \mathrm{mg} / \mathrm{L}$ in parts of Palar river basin in Kancheepuram district of Tamil Nadu. Further, Total Dissolved Solids in the area was found to be in the range from 70 to $467 \mathrm{mg} / \mathrm{L}$. Mukherjee et al. (2011c) use statistical approach to characterized groundwater chemistry. Srinivasamoorthy et al. (2010) studied Mettur region of Tamil Nadu and observed fluoride concentration in groundwater in the range from 0.1 to 2.8 and 0.4 to 4 $\mathrm{mg} / \mathrm{L}$ in pre- and post-monsoon seasons. The anion and cation were observed to be in the order of $\mathrm{Cl}>$ $\mathrm{HCO}_{3}>\mathrm{SO}_{4}>\mathrm{NO}_{3}>\mathrm{PO}_{4}$ and $\mathrm{Na}>\mathrm{Ca}>\mathrm{Mg}>\mathrm{K}$.

Several authors have studied the hydrogeochemistry of groundwater and vulnerability of the aquifer to pollution in hard rock aquifer of the peninsular India. Rina et al. (2011), Singh et al. (2012a and 2012b) studied hydrogeochemical evolution of groundwater. Avtar et al. (2012) used statistical approach to understand groundwater chemistry of Bundelkhand region. Patel et al. (2016) used multivariant statistical analyses to assess the groundwater quality of the Swarnamukhi river basin, Andhra Pradesh. Prasanna et al. (2011), Senthilkumar and Elango, (2013), Rajesh et al. (2015), Brindha and Kavitha (2014), Brindha et al. (2013), Kumar et al. (2014) and Sonkamble et al. (2012) investigated aquifers in various rock domains like granite, gneiss, schist and basalt to enumerate the geochemical evolution of groundwater and its suitability for various use.

Keesari et al. (2014) studied the geochemistry of groundwater using isotopic composition in arid region of western India. The area is affected by salinity whose origin has been found to be leaching of marine sediments besides contribution of evaporates from soil zone. The spatial temporal variation of bromide in the hard rock aquifers in groundwater has been studied by Brindha and Elango (2013). They opined that the sources of bromide are granitic rocks and fertilizers. 
In a significant study, Thivya et al. (2016) evaluated uranium concentration in groundwater, the effect of lithology on hydrochemistry and factors controlling its distribution in granitic aquifers of Madhrai district, Tamil Nadu. Results indicate that the highest uranium concentration i.e. $113 \mu \mathrm{g} / \mathrm{L}$ was found in granitic terrains of this region and about $10 \%$ of the water samples exceed the permissible limit for drinking water.

Mondal and Singh (2011a and 2011b) dealt with the chemical analysis of groundwater affected due to untreated effluents from 80 functioning tanneries forming a tannery belt in Southern India. It was found that the quality of groundwater around the tannery cluster deteriorated mainly due to the extensive use of salts.

\section{Urban Hydrogeology}

The rapid urbanization and exponential increase in extraction of groundwater in urban areas have necessitated studies on urban hydrogeology in cities like Bangaluru (Majumdar, 2012), Chennai (Raju et al., 2013b), Varanasi (Raju et al., 2011) and Delhi (Chatterjee et al., 2009; Sarkar et al., 2016). Most of the urban centres have tendency to overexploit groundwater resources. The groundwater management options suggested for the urban centres mostly includes identification of vulnerable areas and measure to mitigate stress on the groundwater system (Raju et al., 2011; Shekhar et al., 2015).

\section{Groundwater Modeling}

Groundwater modeling is widely used as a tool for applied hydrogeological study. It is often used in assessment of the impact of possible anthropogenic influences on groundwater system. Senthilkumar and Elango (2011) used groundwater modeling to assess the utility of subsurface barrier for augmenting groundwater reserve and to minimize sea discharge of groundwater. Rao et al. (2014) used numerical modeling study for assessing long-term water resources availability in the Godavari basin of India. Shekhar and Rao (2010) discusses about the issues related to groundwater modeling in Palla well field of Delhi. Brindha and Elango (2015) used DRASTIC and models derived from it to map vulnerable zones for pollution in weathered rock aquifers of southern India.

\section{Groundwater Exploration}

Groundwater exploration in India is being carried out mainly by Central Ground Water Board (CGWB). The data is compiled in to thematic maps for use by different agencies and academic institutions. Further the scientific input in to groundwater exploration has been provided by individual researchers. Madhnure (2014) identified weathered aquifers in basaltic and granitic terrain of Nanded District, Maharashatra. They locate the productive zones in the fractured basalt and estimated the aquifer parameters. Similarly, in Kolar district of Karnataka, Hegde et al. (2012) identified the potential aquifers and estimated the aquifer parameters. Shekhar et al. (2009) presented the average value of aquifer parameters for different aquifer system of Delhi using exploration database of CGWB. Mondal and Das (2012) used step drawdown test for recommending safe yield for drinking water supply in Salur Mandal, Vizainagaram in Andhra Pradesh.

\section{Groundwater Recharge and Associated Quality Issues}

The scientific study on groundwater recharge has gained importance of late. This is primarily because of overexploitation of groundwater resources in many parts of India. Kaliraj et al. (2013) proposed suitable artificial groundwater recharge sites along Vaigai upper basin in the Theni district, Tamil Nadu, India. Raju et al. (2013a) designed subsurface dams and studied the impact of dams on water quality and seawater intrusion into the coastal aquifers in the Kalangi River basin, Nellore district, Andhra Pradesh. Renganayaki and Elango (2013) carried out a study to understand the impact of water stored in a check dam on groundwater quality near Chennai, Tamil Nadu. Mondal et al. (2012b) assessed natural groundwater recharge in unconfined aquifers in hard rock aquifers in southern India using entropy-based approach. Selvam et al. (2015) adopted an integrated approach to delineate groundwater recharge potential zones using remote sensing and GIS techniques in Kovilpatti Municipality, Tamil Nadu. Kaliraj et al. (2015) identified groundwater recharge potential zone and suitable sites for artificial recharge structures in the Vaigai basin, Theni district; Tamil Nadu using GISbased multi-parameter weighted overlay method. Kaliraj et al. (2013) studied the groundwater recharge 
potential zones along Vaigai upper basin in the Theni district, Tamil Nadu. Samadder et al. (2011) emphasized on paleochannels and their potential for artificial groundwater recharge in the western Ganga plains. Soni et al. (2014) suggested optimal environmental flow of 50 percent in river Yamuna for it to carry out its function of recharging the flood plain aquifer.

\section{Remote Sensing and GIS Application}

Application of remotely sensed data is widely used for groundwater mapping and targeting groundwater. Anbazhagan and Jothibasu (2014) carried out sustainable groundwater potential mapping through geoinformatics in the Uppar Odai sub-basin in Amravati River basin, southern India. The geomorphology and lineaments were interpreted from IRS P6 LISS III satellite data. This was further integrated with resistivity data for generation of groundwater potential map. Chowdhary et al. (2009) had applied remote sensing and GIS based study and assessed groundwater potential of the coastal in West Medinipur district of West Bengal.

Magesh et al. (2012) integrated the remote sensing data on geographical information system platform for the exploration of groundwater in Theni district, Tamil Nadu. Deepika et al. (2013) identified the groundwater potential zones of Gangolli baisn of Karnataka using GIS. Similarly with the help of remote sensing and GIS, Avinash et al. (2011) mapped geomorphic features of Gurpur river basin of Karnataka, India. Varade et al. (2012) used remote sensing and GIS technique to identify potential sites for water conservation measures like gully plugs, earthen check dams, continuous contour trenches, percolation tanks, cement bandhara, aforestation and farm ponds in Nagpur district of Maharashtra. Groundwater potentiality has been studied by adopting remote sensing and GIS technique in hard rock aquifers in West Bengal by Jha et al. (2012) and in the arid region of western India by Mukherjee et al. (2012b).

In addition to remote sensing, various maps and existing data were placed in GIS platform to work out the data gap on various investigations in terms of mapping of aquifers and groundwater potentiality in parts of Karnataka state underlain by hard rock aquifers (Vittala et al., 2013) and in Punjab by
Mukherjee et al. (2011b). Water level situation and other layers was field data. Remote sensing in a GIS platform was tried in alluvial areas successfully by Ganapman et al. (2009) and Saha et al. (2006). The overlay analyses had also tried to prepare vulnerability map of the coastal aquifers (Sathis and Elango 2011). Gopinath et al. (2014) had applied geospatial technology in drought monitored by NDVI mainly using Terra satellite products in southern parts of India. Rajaveni et al. (2015) researched on delineating groundwater perspective zones in Nalgonda district of Telangana state. Mukherjee and Veer (2014) has applied artificial neural network and image processing for development of water resource management plan in parts of Hindon basin. Further, Mukherjee et al. (2015b) discussed about application of geospatial and geostatistical techniques for groundwater potential zone delineation.

\section{Coastal Aquifers}

The costal aquifers are important as they are sustaining huge demand from drinking and irrigation. On account of heavy abstraction the coastal areas have also become priority research sites. Rina et al. (2011 and 2013) studied hydrogeochemistry of Sabarmati basin including its coastal aquifers. Selvam et al. (2013) assessed the groundwater quality around Tuticorin Corporation limits, Tamilnadu vis-a-vis utility of water for different purposes. Sivasubramanian et al. (2013) identified the chemical processes that control hydrochemistry in Kadaladi block of Ramanathapuram District, Tamilnadu. Prasanth et al. (2012) carried out a hydro-geochemical study in Alappuzha district of Kerala to assess suitability of water for different uses. Mondal et al. (2012a) used geophysical survey in industrial belt of Southern India for estimation of salinity variation. Chandrasekar et al. (2013) identified seawater intrusion in the aquifers of southern Tamil Nadu. Prasanth et al. (2012) examined the suitability of ground water quality for irrigation and domestic purpose in of Alappuzha District, Kerala. Sathish and Elango (2011) identified groundwater quality variation and proposed vulnerability map of the south Chennai coastal aquifer, while Sankaran et al. (2012) identified groundwater pollution and saline intrusion through Uppanar River, which flows parallel to sea coast in Cuddalore. Singh and Jha (2014) researched on tide dynamics in the coastal aquifer system. In another significant work, 
Jha and Singh (2014) applied genetic algorithm techniques to model tide-aquifer interaction. Reddy and Gunaseker (2013) studied the groundwater quality in coastal areas of Andhra Pradesh and its impact on human health particularly the kidney.

\section{Groundwater Management}

Sarkar et al. (2016) use DPSIR (Drivers, Pressures, State, Impacts, and Responses) approach and successfully evaluated the groundwater environment of Delhi. Further, Shekhar et al. (2015) explained various ways of groundwater management in North district of NCT Delhi. The authors divided the district into three distinct hydrogeological domains based on the occurrence and availability of groundwater similarity. Groundwater potential in these domains were worked out.

Madhnure et al. (2015) has carried out an integrated study to assess groundwater development possibility in semi-arid Madhram watershed in Telangana. Higher transmissibility, specific yield and infiltration rate were observed in the recharge area and those decrease gradually towards the discharge area. Analyses and mapping of water levels are essential inputs for groundwater management. In a significant work, Mondal and Singh (2012) applied entropy based approach to assess the groundwater monitoring networks stations and water levels maps those are prepared based on existing monitoring stations. Rajaveni et al. (2014) explained how to assess the water levels in relation to dykes, drainage, lineament and weathered zone thickness. The utility of geophysical investigation to understood the hydrogeological complexities in granitic terrains in Telangana state has been described by Sonkamble et al. (2014). In an interesting study, Yogeswar et al. (2012) investigated the impact of sewage irrigation and groundwater contamination around Roorkee region in upper Ganga plain using advanced geophysical technique like direct current resistivity and radio magnetotelluric methods.

\section{References}

Ali S, Thakur S K, Sarkar S and Shekhar S (2016) Worldwide contamination of water by fluoride Environ Chem Lett doi: 10.1007/s10311-016-0563-5

Alam M O, Shaikh W A, Chakraborty S, Avishek K and

\section{Conclusions}

It is observed that the diverse hydrogeological setup of India and the varied forcing on groundwater system has resulted in hydrogeological domain specific issues. This requires remedial measures specific to the hydrogeological domains. It is concluded that the IndoGangetic Plains has twin problem of groundwater overexploitation in western part and its quality deterioration at places. The arsenic contamination of groundwater is mainly noticed in eastern part of the Gangatic Plains in states like West Bengal, Bihar and Uttar Pradesh. While fluoride contamination in groundwater is mainly restricted to arid and semiarid regions of the basin. Hardrock areas also show overexploitation of the groundwater resources in certain pockets. Further, fluoride contamination in groundwater has been generally observed in hard rock region of southern India. The inland salinity in western India and coastal aquifer salinity needs to be prudently managed to prevent further water quality deterioration. This becomes important as the vulnerability of coastal aquifers to sea water intrusion and problem of inland salinity upconing are becoming major issues. Remote sensing and various geophysical and isotopic technique have proved to be successful tools for groundwater exploration mainly in hardrock areas of the country. The efficacy of numerical modeling for groundwater resource management has been established in different hydrogeologic environment in India.

\section{Acknowledgments}

The support and guidance of Prof. D M Banerjee is duly acknowledged. SA acknowledges Non NET fellowship provided by Department of Geology, University of Delhi. D Saha and Dr SS Vittala acknowledge the help and guidance of Chairman CGWB in preparation of the document.

\footnotetext{
Bhattacharya T (2016) Groundwater Arsenic Contamination and Potential Health Risk Assessment of Gangetic Plains of Jharkhand, India Expo Health 8 125142 doi: 10.1007/s12403-015-0188-0
}

Alam F and Umar R (2013) Trace Elements in Groundwater of 
Hindon-Yamuna Interfluve Region, Baghpat District, Western Uttar Pradesh Journal of Geological Society of India 81 422-428

Anbazhagan S and Jothibasu A (2014) Geoinformatics in groundwater potential mapping and sustainable development: a case study from southern India Hydrological Sciences doi: 10.1080/02626667.2014. 990966

Avinash K, Jayappa K S and Deepika B (2011) Prioritization of subbasins based on geomorphology and morphometric analysis using remote sensing and geographic information system (GIS) techniques Geocarto International doi: 10.1080/10106049.2011.606925

Avtar R, Kumar P, Singh C K, Verma R L, Thakur J K and Mukherjee S (2012) Hydrogeochemical assessment of groundwater quality of Bundelkhand, India using statistical approach Water Qual Expo Health 5 105-115 doi: 10.1007/ s12403-013-0094-2

Banerjee et al. (2012) Contemporary Groundwater Pollution Studies in India Proc Indian Natn Sci Acad 78 333-342

Bawa N, Jain V, Shekhar S, Kumar N and Jyani V (2014) Controls on morphological variability and role of stream power distribution pattern, Yamuna River, western India Geomorphology 227 60-72 doi: org/10.1016/ j.geomorph.2014.05.016

Bhattacharya P, Samal A C, Majumdar J and Santra S C (2010a) Arsenic Contamination in Rice, Wheat, Pulses, and Vegetables: A Study in an Arsenic Affected Area of West Bengal, India Water Air Soil Pollut 213 3-13 doi: 10.1007/ s11270-010-0361-9

Bhattarcharya P, Samal A C, Majumdar J and Santra S C (2010b) Accumulation of arsenic and its distribution in rice plant (Oryza sativa L.) in Gangetic West Bengal, India Paddy Water Environ 8 63-70 doi: 10.1007/s10333-009-0180-z

Brindha K and Elango L (2015) Cross comparison of five popular groundwater pollution vulnerability index approaches Journal of Hydrology 524 597-613 doi.org/10.1016/ j.jhydrol.2015.03.003

Brindha K and Kavitha R (2014) Hydrochemical assessment of surface water and groundwater quality along Uyyakondan channel, south India Environ Earth Sci 73 5383-5393 doi: 10.1007/s12665-014-3793-5

Brindha K, Vaman K V N, Srinivasan K, Babu M S and Elango L (2013) Identification of surface water-groundwater interaction by hydrogeochemical indicators and assessing its suitability for drinking and irrigational purposes in Chennai, Southern India Appl Water Sci 4 159-174 doi: 10.1007/s13201-013-0138-6

Brindha K and Elango L (2013) Causes for Variation in Bromide Concentration in Groundwater of a Granitic aquifer International Journal of Research in Chemistry and Environment 3 163-171 ISSN 2248-9649

Brindha K, Rajesh R, Murugan and Elango L (2010) Natural and Anthropogenic Influence on the Fluoride and Nitrate Concentration of Groundwater in Parts of Nalgonda District, Andhra Pradesh, India Journal of Applied Geochemistry 1 231-241

Buragohain M, Bhuyan B and Sarma H P (2010) Seasonal variations of lead, arsenic, cadmium and aluminium contamination of groundwater in Dhemaji district, Assam, India Environ Monit Assess 170 345-351 doi: 10.1007/ s10661-009-1237-6

Chatterjee D, Halder D, Majumder S, Biswas A, Nath B, Bhattacharya P, Bhowmick S, Goswami A M, Debasree S, Rasmani H, Maity P B, Chatterjee D, Mukherjee A and Bundschuh J (2010) Assessment of arsenic exposure from groundwater and rice in Bengal Delta Region, West Bengal, India Water Research, India Water research 44 5803-5812 doi: doi:10.1016/j.watres.2010.04.007

Chatterjee R, Gupta B K, Mohiddin S K, Singh P N, Shekhar S and Purohit R (2009) Dynamic groundwater resources of National Capital Territory, Delhi: assessment, development and management options Environ Earth Sci 59 669-686

Chakraborti D, Rahman M M, Ahamed S, Dutta R N, Pati S and Mukherjee S C (2016) Arsenic contamination of groundwater and its induced health effects in Shahpur block, Bhojpur district, Bihar state, India: risk evaluation Environ Sci Pollut Res 23 9492-9504 doi: 10.1007/s11356-0166149-8

Chakraborti D, Singh E J, Das B and Shah B A (2008) Groundwater arsenic contamination in Manipur, one of the seven North-Eastern Hill states of India: a future danger Environ Geol 56 381-390 doi: 10.1007/s00254-007-1176$\mathrm{x}$

Chakraborty D, Mukherjee S C, Pati S, Sengupta M K, Rahman M M, Chowdhury U K, Lodh D, Chanda C R, Chakraborty A K and Basu G K (2003) Arsenic groundwater contamination in Middle Ganga Plain, Bihar, India: A future Danger? Environ Health Perspect 111 1194-1201

Chandrasekar N, Selvakumar S, Srinivas Y, Wilson J S J, Peter T S and Magesh N S (2013) Hydrogeochemical assessment of groundwater quality along the coastal aquifers of southern Tamil Nadu, India Environ Earth Sci doi: 10.1007/ s12665-013-2864-3 
Chowdhury A, Jha M K, Chowdary V M and Mal B C (2009) Integrated remote sensing and GIS based approach for assessing groundwater potential in West Medinipur district, West Bengal, India International Journal of Remote Sensing 30 231-250 doi: 10.1080/01431160802270131

Chauhan V S, Nickson R T, Chauhan D, Iyengar L and Sankararamakrishnan N (2009) Ground water geochemistry of Ballia district, Uttar Pradesh, India and mechanism of arsenic release Chemosphere 75 3-91 doi: 10.1016/ j.chemosphere.2008.11.065

Chetia M, Chatterjee S, Banerjee S, Nath M J, Singh L, Srivastava R B and Sharma H P (2011) Groundwater arsenic contamination in Brahmaputra river basin: a water quality assessment in Golaghat (Assam), India Environ Monit Assess 173 371-385 doi: 10.1007/s10661-010-1393-8

CGWB (2014) Dynamic groundwater resources of India. Faridabad July

Dar MA, Sankar K and Dar I A (2011) Fluorine contamination in groundwater: a major challenge Environ Monit Assess 173 955-968 doi: 10.1007/s10661-010-1437-0

Dasgupta S, Das I C, Subramanian S K and Dadhwal V K (2014) Space-based gravity data analysis for groundwater storage estimation in the Gangetic plain, India Current Science $107832-844$

Deepika B, Avinash K and Jayappa K S (2013) Integration of hydrological factors and demarcation of groundwater prospect zones: insights from remote sensing and GIS techniques Environ Earth Sci 70 1319-1338 doi: 10.1007/ s12665-013-2218-1

Dubey C S, Mishra B K, Shukla D P, Singh R P, Tajbakhsh and Sakhare P (2012) Anthropogenic arsenic menace in Delhi Yamuna Flood Plains Environ Earth Sci 65 131-139 doi: 10.1007/s12665-011-1072-2

Dwivedi S N and Singh R K (2015) Inter-aquifer water transfer through combination well for artificial recharging of the deeper aquifer system in Patna urban area Current science 10108 1219-21

Ganapuram S, Kumar G T V, Krishna I V M and Kahya E (2009) Mapping of groundwater potential zones in the Musi basin using remote sensing data and GIS Advances in Engineering Software 40 506-518 doi: org/10.1016/j.advengsoft.2008. 10.001

Garai R, Chakraborty A K, Dey S B and Saha K C (1984) Chronic arsenic poisoning from tube-well water JInd Med Assoc 82 34-35

Gopinath G, Ambili G K, Gregory S J and Anusha C K (2014) Drought risk mapping of south-western state in the Indian peninsula - A web based application Journal of Environmental Management pp. 1-7. http://dx.doi.org/ 10.1016/j.jenvman.2014.12.040

Hegde S S, Kumaresan K, Hunse T M and Najeeb K M (2012) Deep ground water exploration in over-exploited Kolar district, Karnataka Memoir Geol Soc India 80 17-37

Hussain J, Hussain I and Arif M (2013) Fluoride contamination in groundwater of central Rajasthan, India and its toxicity in rural habitants Toxicological \& Environmental Chemistry 95 1048-1055 doi: org/10.1080/02772248.2013.832545

Jangle N, Sharma V and Dror D M (2016) Statistical geospatial modelling of arsenic concentration in Vaishali district of Bihar India Sustain Water Resour Manag doi: 10.1007/ s40899-016-0049-4

Jha M K and Singh A (2014) Application of genetic algorithm technique to inverse modeling of tide-aquifer interaction Environ Earth Sci 7136553672 doi: 10.1007/s12665-0132758-4

Jha M K, Chowdary V M and Chowdhury A (2012) Groundwater assessment in Salboni Block, West Bengal (India) using remote sensing, geographical information system and multicriteria decision analysis techniques Hydrogeology Journal 18 1713-1728 doi:10.1007/s10040-010-0631-z

Kaliraj S, Chandrasekar N and Magesh N S (2015) Evaluation of multiple environmental factors for site-specific groundwater recharge structures in the Vaigai River upper basin, Tamil Nadu, India, using GIS-based weighted overlay analysis Environ Earth Sci 74 4355-4380 doi: 10.1007/ s12665-015-4384-9

Kaliraj S, Chandrasekar N and Magesh N S (2013) Identification of potential groundwater recharge zones in Vaigai upper basin, Tamil Nadu, using GIS-based analytical hierarchical process (AHP) technique Arab J Geosci doi: 10.1007/ s12517-013-0849-x

Keesari T, Kulkarni U P, Deodhar A, Ramanjaneyulu P S, Sanjukta A K and Kumar U S (2014) Geochemical characterization of groundwater from an arid region in India Environ Earth Sci doi: 10.1007/s12665-013-2878-x

Khan MAK, Umar R and Lateh H (2010) Study of Trace Elements in Groundwater of Western Uttar Pradesh, India Scientific Research and Essays 5 3175-3182

Kumar M, Rahman M M, Ramanathan A L and Naidu R (2016) Arsenic and other elements in drinking water and dietary components from the middle Gangetic plain of Bihar, India: Health risk index Science of the Total Environment 539 125-134 doi: org/10.1016/j.scitotenv.2015.08.039

Kumar M, Rao M S, Deka J P, Ramanathan A L and Kumar B 
(2015) Integrated hydrogeochemical, isotopic and geomorphological depiction of the groundwater salinization in the aquifer system of Delhi, India Journal of Asian Earth Sciences 111 36-947 doi: org/10.1016/j.jseaes.2015. 08.018

Kumar S K, Logeshkumaran A, Magesh N S, Godson P S and Chandrasekar N (2014). Hydro-geochemistry and application of water quality index (WQI) for groundwater quality assessment, Anna Nagar, part of Chennai City, Tamil Nadu, India Appl Water Sci 5 335-343 doi: 10.1007/ s13201-014-0196-4

Kumar S, Baier K, Jha R and Azzam R (2013) Status of arsenic contamination in potable water of Northern areas of Mizoram State and its adjoining areas of Southern Assam, India Arab J Geosci 6 383-393 doi: 10.1007/s12517-011-0373-9

Kumar P, Kumar M, Ramanathan A L and Tsujimura M (2010) Tracing the factors responsible for arsenic enrichment in groundwater of the middle Gangentic Plain, India: a source identification perspective Envion Geochem Health 32129 146

Halder D, Bhowmick S, Biswas A, Mandal U, Nriagu J, Nath D, Mazumdar G, Chatterjee D and Bhattacharya P (2012) Consumption of Brown Rice: A Potential Pathway for Arsenic Exposure in Rural Bengal Environ Sci Technol 46 4142-4148 doi: 10.1021/es204298a

MacDonald A M, Bonsor H C, Taylor R, Shamsudduha M, Burgess W G, Ahmed K M, Mukherjee A, Zahid A, Lapworth D, Gopal K, Rao M S, Moench M, Bricker S H, Yadav S K, Satyal Y, Smith L, Dixit A, Bell R, Van Steenbergen F, Basharat M, Gohar M S, Tucker J, Calow R C and Maurice L (2015) Groundwater resources in the Indo Gangetic Basin: resilience to climate change and abstraction British Geological Survey Open Report OR/ 15/047, 63pp

Madhnure P, Peddi N R and Allani D R (2015) An integrated hydrogeological study to support sustainable development and management of groundwater resources: a case study from the Precambrian Crystalline Province, India Hydrogeol J doi: 10.1007/s10040-015-1342-2

Madhnure P (2014) Groundwater Exploration and Drilling Problems Encountered in Basaltic and Granitic Terrain of Nanded District, Maharashtra Geol Soc India 84 341-351

Mahanta C, Enmark G, Nordborg D, Sracek O, Nath B, Nickson R T, Herbert R, Jacks G, Mukherjee A, Ramanthan A L, Choudhury R and Bhattachaya P (2015) Hydrogeochemical controls on mobilization of arsenic in groundwater of a part of Brahmaputra river floodplain, India Journal of Hydrology: Regional Studies 4 154-171

Magesh N S, Chandrasekar N and Soundranayagam J P (2012) Delineation of groundwater potential zones in Theni district, Tamil Nadu, using remote sensing, GIS and MIF techniques Geoscience Frontiers 3 189-196

Majumdar A K (2012) Water Problems of Bengaluru - the Fastest Growing City of India Jour Geol Soc India 79424

Manikandan S, Chidambaram S, Ramanathan AL, Prasanna M V, Karmegam U, Singaraja C, Paramaguru P and Jainab I (2014) A study on the high fluoride concentration in the magnesium-rich waters of hard rock aquifer in Krishnagiri district, Tamilnadu, India Arab J Geosci 7 273-285 doi: $10.1007 / \mathrm{s} 12517-012-0752-\mathrm{x}$

Mondal N C and Singh V P (2012) Evaluation of groundwater monitoring network of Kodaganar River basin from Southern India using entropy Environ Earth Sci 66 11831193 doi: 10.1007/s12665-011-1326-Z

Mondal N C, Singh V P and Ahmed S (2012a) Delineating shallow saline groundwater zones from Southern India using geophysical indicators Environ Monit Assess 185 48694886 DOI: 10.1007/s10661-012-2909-1

Mondal N C, Singh V P and Ahmed S (2012b) Entropy-Based Approach for Assessing Natural Recharge in Unconfined Aquifers from Southern India Water Resour Manage 26 2715-2732 doi: 10.1007/s11269-012-0042-0

Mondal N C and Das S N (2012) Evaluation and Augmentation of Safe Drinking Water Supply Schemes in Salur Mandal, Vizainagaram District, Andhra Pradesh Geol Soc India 80 $57-64$

Mondal N C and Singh V P (2011a) Hydrochemical analysis of salinization for a tannery belt in Southern India Journal of Hydrology 405 235-247

Mondal N C and Singh V P (2011b) Chloride migration in groundwater for a tannery belt in Southern India Environ Monit Assess 184 2857-2879 doi: 10.1007/s10661-0112156-x

Mukherjee A, Saha D, Harvey C F, Taylor R G, Ahmed K M and Bhanja S N (2015a) Groundwater systems of the Indian Sub-Continent Journal of Hydrology: Regional Studies 4 $1-14$

Mukherjee S, Mallick J, SinghC K, Al-Wadi H, Ahmed M, Rahman A and Shashtri S (2015b) Geospatial and geostatistical approach for ground water potential zone delineation Hydrological Processes 29 395-418 doi: 10.1002/ hyp. 10153 
Mukherjee S (2015) Climate change includes variation in groundwater quality Jour Earth science and climatic change 5

Mukherjee S and Veer V (2014) Water resource management in a part of Hindon basin, India using artificial neural networking and image processing technique International Journal of Innovation and Advancement in Computer Sciences 3 96117

Mukherjee A, Scanlon B R, Fryar A E, Saha D, Ghosh A, Chowdhuri S and Mishra R (2012a) Solute chemistry and arsenic fate in aquifers between the Himalayan foothills and Indian craton (including central Gangetic plain): Influence of geology and geomorphology Geochimicaet Cosmochimica Acta 90 283-302 doi: org/10.1016/ j.gca.2012.05.015

Mukherjee P, Singh C K and Mukherjee S (2012b) Delineation of groundwater potential zones in arid region of India - A Remote Sensing and GIS approach Water Resour Manage 26 2643-2672 doi: 10.1007/s11269-012-0038-9

Mukherjee S, Singh C K, Shashtri S and Singh A (2011a) Quantitative modeling of groundwater in Satluj River basin of Rupnagar district of Punjab using remote sensing and geographic information system Environ Earth Sci 62 871881 doi: $10.1007 / \mathrm{s} 12665-010-0574-7$

Mukherjee S, Singh C K, Shashtri S, Rina K, Avatar R, Singh A and Singh R P (2011b) Application of GWQI to assess effect of land use change on groundwater quality in lower Shiwaliks of Punjab: remote sensing \& GIS based approach Water Resour Manage 25 1881-1898 doi: 10.1007/s11269011-9779-0

Mukherjee S, Avtar R, Singh C K, Kumar P and Verma R (2011c) A comparative study of Hydrogeochemistry of Ken-Betwa Rivers of Bundelkhand using statistical approach Water Qual Expo Health 2 169-179 doi: 10.1007/s12403-0100035-2

Mukherjee S, Singh C K, Rina K, Singh R P, Shashtri S and Kamal V (2011d) Geochemical Modeling of High Fluoride Concentration in Groundwater of Pokhran Area of Rajasthan, India Bull Environ Contam Toxicol 86 152-158 doi: 10.1007/s00128-011-0192-4

Mukherjee A, Fryar A E, Scanlon B R, Bhattacharya P and Bhattacharya A (2011e) Elevated arsenic in deeper groundwater of western Bengal basin, India: Extents and controls from regional to local scale Applied Geochemistry 26600613

Oinam J D, Ramanthan A L and Singh G (2012) Geochemical and statistical evaluation of groundwater in Imphal and Thoubal district of Manipur, India Journal of Asian Earth Sciences 48 136-149

Pandey A C, Singh S K and Saha D (2015) Geological and hydrogeomorphological control on iron-arsenic contamination in groundwater in part of Gangetic plain, India Int Journal of Advances in Remote Sensing and GIS 4

Patel P, Raju N J, Reddy B C S R, Suresh U, Gossel W and Wycisk P (2016) Geochemical processes and multivariate statistical analysis for the assessment of groundwater quality in the Swarnamukhi River basin, Andhra Pradesh, India Environ Earth Sci 75611 doi: 10.1007/s12665-0155108-X

Prasanth S V S, Magesh N S, Jitheshlal K V, Chandrasekar N and Gangadhar K (2012) Evaluation of groundwater quality and its suitability for drinking and agricultural use in the coastal stretch of Alappuzha District, Kerala, India Appl Water Sci doi: 10.1007/s13201-012-0042-5

Prasanna M V, Chidambaram S, Hameed AS and Srinivasamoorthy K (2011) Hydrogeochemical analysis and evaluation of groundwater quality in the Gadilam river basin, Tamil Nadu, India J Earth Syst Sci 120 85-98 Indian Academy of Sciences

Rajesh R, Brindha K and Elango L (2015) Groundwater Quality and its Hydrochemical Characteristics in a Shallow Weathered Rock Aquifer of Southern India Water Qual Expo Health 7 515-524 doi: 10.1007/s12403-015-0166-6

Rajaveni S P, Brindha K and Elango L (2015) Geological and geomorphological controls on groundwater occurrence in a hard rock region Appl Water Sci doi: 10.1007/s13201-0150327-6

Rajaveni S P, Brindha K, Rajesh R and Elango L (2014) Spatial and Temporal Variation of Groundwater Level and its Relation to Drainage and Intrusive Rocks in a part of NalgondaDistrict, Andhra Pradesh, India J Indian Soc Remote Sens doi: 10.1007/s12524-013-0328-6

Raju N J (2016) Prevalence of fluorosis in the fluoride enriched groundwater in semi-arid parts of eastern India: Geochemistry and health implications Quaternary International doi: org/10.1016/j.quaint.2016.05.028

Raju N J, Reddy T V K, Muniratnam P, Gossel W and Wycisk P (2013a) Managed Aquifer Recharge (MAR) by the Construction of Subsurface Dams in the Semi-arid Regions: A Case Study of the Kalangi River Basin, Andhra Pradesh Journal Geological Society of India 82 657-665

Raju AP, Chandrasekar and Saravanan S (2013b) Spatial Analysis of Groundwater Quality Investigation in North Chennai, 
Tamilnadu, India International Journal of Water Research 1 1-6

Raju N J, Dey S, Gossel W and Wycisk P (2012) Fluoride hazard and assessment of groundwater quality in the semiaridUpper Panda River basin, Sonbhadra District, Uttar Pradesh, India Hydrological Sciences 57 1433-1452

Raju N J (2012a) Evaluation of hydrogeochemical processes in the Pleistocene aquifers of Middle Ganga Plain, Uttar Pradesh, India Environ Earth Sci 65 1291-1308 doi: 10.1007/s12665-011-1377-1

Raju N J (2012b) Arsenic Exposure through Groundwater in the Middle Ganga Plain in the Varanasi Environs, India: A Future Threat Jour Geol Soc India 79 302-314

Raju N J, Shukla U K and Ram R (2011) Hydrogeochemistry for the assessment of groundwaterquality in Varanasi: a fasturbanizing center in Uttar Pradesh, India Environ Monit Assess 173 279-300

Raju N J, Dey S and Das Kaushik (2009) Fluoride contamination in groundwaters of Sonbhadra District, Uttar Pradesh, India Current Science 96 979-985

Rao K H V D, Rao V V, Dadhwal V K, Sharma J R and Jyothsna $\mathrm{R}$ (2014) Transforming to hydrological modelling approach for long-term water resources assessment under climate change scenario - a case study of the Godavari Basin, India Current Science 106 293-299

Reddy D V and Gunasekar A (2013) Chronic kidney disease in two coastal districts of Andhra Pradesh, India: role of drinking water Environ Geochem Health 35 439-454 doi: 10.1007/s10653-012-9506-7

Rina K, Dutta P S, Singh C K and Mukherjee S (2013) Isotopes and ion chemistry to identify salinization of coastal aquifers of Sabarmati River Basin Current Science 104 335-344

Rina K, and Dutta P S and Mukherjee S (2011) Characterization and Evaluation of processes governing the groundwater quality in parts of the Sabarmati basin, Gujarat using hydrochemistry integrated with GIS Hydrological Processes 26 1538-1551 doi: 10.1002/hyp.8284

Rodell M, Velicogna I and Famiglietti J S (2009) Satellite-based estimates of groundwater depletion in India Nature $\mathbf{4 6 0}$ 999-1003

Renganayaki S P and Elango L (2013) Impact of recharge from a check dam on groundwater quality and assessment of suitability for drinking and irrigation purposes Arab $J$ Geosci doi: 10.1007/s12517-013-0989-z

Saha D and Sahu S (2016) A decade of investigations on groundwater arsenic contamination in Middle Ganga Plain, India Environ Geochem Health doi: 10.1007/s10653-015- $9730-\mathrm{z}$

Saha D and Alam F (2014) Groundwater vulnerability assessment using DRASTIC and Pesticide DRASTIC models in intense agriculture area of the Gangetic plains, India Environ Monit Assess doi: 10.1007/s10661-014-4041-x

Saha D and Shukla R R (2013) Genesis of arsenic-rich groundwater and search for alternative safe-aquifers in the Gangetic plains, India Water and Environment Research 852254 2264

Saha D, Dwivedi S N, Roy G R and Reddy D V (2013) Isotopebased investigation on the groundwater flow and recharge mechanism in a hard-rock aquifer system: the case of Ranchi urban area, India Hydrogeology Journal doi: 10.1007/ s10040-013-0974-3

Saha D, Sahu S and Chandra PC (2011) As safe alternate aquifers and their hydraulic characteristics in contaminated areas of Middle Ganga Plain, Eastern India Environ Monit Assess 175331348 doi: 10.1007/s10661-010-1535-z

Saha D, Dhar Y R and Vittala S S (2010) Delineation of groundwater development potential zones in parts of marginal Ganga Alluvial Plain in South Bihar, Eastern India Environ Monit Assess 165179191

Saha D, Sarangam H, Diwedi S N and Bhartariya K J (2009) Evaluation of hydrochemical processes in the arsenic contaminated alluvial aquifers in parts of Mid-Ganga basin, Bihar, India Environmental Earth Sciences doi: 10.1007/ s12665-009-0392-y

Saha D (2009) Arsenic groundwater contamination in parts of middle Ganga plain, Bihar Current Science 97

Saha D, Dhar Y R and Das S (2006) Delineating ground water potential zones in the marginal alluvial areas of Gangetic Plain-a case study from Nalanda district, Bihar Indian Journal of Geosciences 60 181-192

Sahu S and Saha D (2014a) Geomorphologic, stratigraphic and sedimentologic evidences of tectonic activity in Sone-Ganga alluvial tract in Middle Ganga Plain, India J Earth System Science 123 1335-1347

Sahu S and Saha D (2014b) Correlation between stratigraphy, flood plain geomorphology and arsenic distribution in groundwater of in Middle Ganga Plain, Bihar, India Environ Earth Science doi: 10.1007/s12665-014-3637-3

Sahu S, Raju N J and Saha D (2010) Active tectonics and geomorphology in the Sone-Ganga alluvial tract in midGanga Basin, India Quaternary International doi: 10.1016/ j.quaint.2010.05.023

Sankar M S, Vega M A, Defoe P P, Kibria M G, Ford S, Telfeyan K, Neal A, Mohajerin T J, Hettiarachchi G M, Barua S, 
Hobson C, Johannesson K and Datta S (2014) Elevated arsenic and manganese in groundwaters of Murshidabad, West Bengal, India Sci Total Environ 488-489 570-579 doi.org/10.1016/j.scitotenv.2014.02.077

Sankaran S, Sonkamble S, Krishnakumar K and Mondal N C (2012) Integrated approach for demarcating subsurface pollution and saline water intrusion zones in SIPCOT area: a case study from Cuddalore in Southern India Environ Monit Assess 184 5121-5138 doi: 10.1007/ s10661-011-2327-9

Sarkar A, Ali S, Kumar A, Shekhar S and Rao S V N (2016) Groundwater Environment in Delhi, India. In Groundwater Environment in Asian Cities. 1eds Elsevier Inc. http:// dx.doi.org/10.1016/B978-0-12-803166-7.00005-2

Sarkar A and Shekhar S (2015) The controls on spatial and temporal variation of hydrochemical facies and major ion chemistry in groundwater of South West District, Delhi, India Environ Earth Sci 74 7783-7791

Sarkar A and Shekhar S (2013) An Assessment of Groundwater Quality of Lesser Contaminated Aquifers in North District of Delhi Proc Indian Natn Sci Acad 79 235-243

Sathish S and Elango L (2011) Groundwater Quality and Vulnerability Mapping of an Unconfined Coastal Aquifer Journal of Spatial Hydrology $\mathbf{1 1}$

Saxena V and Ahmed S (2003) Inferring the chemical parameters for the dissolution of fluoride in groundwater Environ Geol 43 731-736 doi: 10.1007/s00254-002-0672-2

Senthilkumar M and Elango L (2013) Geochemical processes controlling the groundwater quality in lower Palar river basin, southern India J Earth Syst Sci 122 419-432 Indian Academy of Sciences

Shah ZA and Umar R (2015) Stable Isotopic and Hydrochemical Studies in a Part of Central Ganga Basin Journal Geological Society of India $\mathbf{8 5}$ 706-716

Shah B A (2015) Status of groundwater arsenic pollution of Mirzapur district in Holocene aquifers from parts of the Middle Ganga Plain, India Environ Earth Sci 73 15051514 doi: 10.1007/s12665-014-3501-5

Shah B A (2013) Arsenic in groundwater, Quaternary sediments and suspected river sediments from the Middle Gangetic Plain, India: Distribution, field relations and geomorphological setting Arab J Geosci 7 3525-3536 doi: 10.1007/s12517-013-1012-4

Shah B A (2012) Role of Quaternary stratigraphy on arseniccontaminated groundwater from parts of Barak Valley, Assam, North-East India Environ Earth Sci 66 2491-2501 doi: 10.1007/s12665-011-1472-3
Shah B A (2010) Arsenic-contaminated groundwater in Holocene sediments from part of Middle Ganga Plain, Uttar Pradesh, India Current Science 98 1359-1363

Samadder R K, Kumar S and Gupta R P (2011) Paleochannels and their potential for artificial groundwater recharge in the western Ganga plains Journal of Hydrology $400154-$ 164

Shekhar S, Mao R S K and Imchen E B (2015) Groundwater management options in North District of Delhi, India: a groundwater surplus region in over-exploited aquifers $J$ Hydrol Reg Stud 4212-226 doi: 10.1016/j.ejrh.2015.03.003.

Shekhar S and Sarkar A (2013) Hydrogeological characterization and assessment of groundwater quality in shallow aquifers in vicinity of Najafgarh drain of NCT Delhi J Earth Syst Sci 122 43-54 doi: 10.1007/s12040-012-0256-9

Shekhar S and Rao S V N (2010) Groundwater management in Palla well field of Delhi using numerical modeling techniquea case study Silver Jubilee Publication-II 2546

Shekhar S and Prasad R K (2009) The groundwater in the Yamuna flood plain of Delhi (India) and the management options Hydrogeology Journal 17 1557-1560

Selvam S, Farooq AD, Magesh N S, Singaraja C, Venkatramanan S and Chung S Y (2015) Application of remote sensing and GIS for delineating groundwater recharge potential zones of Kovilpatti Municipality, Tamil Nadu using IF technique Earth Sci Information doi: 10.1007/s12145-015-0242-2

Selvam S, Manimaran G and Sivasubramanian P (2013) Hydrochemical characteristics and GIS-based assessment of groundwater quality in the coastal aquifers of Tuticorin corporation, Tamilnadu, India Appl Water Sci 3 145-159 doi: 10.1007/s13201-012-0068-8

Senthilkumar M and Elango L (2011) Modelling the impact of a subsurface barrier on groundwater flow in the lower Palar River basin, southern India Hydrogeology Journal 19917 928 doi: 10.1007/s10040-011-0735-0

Singh S, Raju N J and Ramakrishna C H (2015) Evaluation of Groundwater Quality and Its Suitability for Domestic and Irrigation Use in Parts of the Chandauli-Varanasi Region, Uttar Pradesh, India Journal of Water Resource and Protection 7 482-497

Singh A and Jha M K (2014) A data-driven approach for analyzing dynamics of tide-aquifer interaction in coastal aquifer systems. (Report)

Singh C K and Mukherjee S (2014) Aqueous geochemistry of fluoride enriched groundwater in arid part of western India Environmental Science and pollution research doi: 10.1007/ s11356-014-3504-5 
Singh N, Singh R P, Mukherjee S, McDonald K and Reddy K J (2013a) Hydrogeological processes controlling the release of arsenic in parts of 24 Parganas district, West Bengal Environmental Earth Sciences 72 111-118 doi: 10.1007/ s12665-013-2940-8

Singh C K, Rina K, Singh R P and Mukherjee S (2013b) Geochemical characterization and heavy metal contamination of groundwater in Satluj River Basin Environ Earth Sci 71 201-216. doi:10.1007/s12665-013-2424-x

Singh C K, Rina K, Singh N, Mallick J and Mukherjee S (2012) Fluoride enrichment in aquifers of Thar Desert: Controlling Factors and its Geochemical Modeling Hydrological Processes doi: 10.1002/hyp.9247

Singh C K, Rina K, Mallick J, Singh R P, Singh N, Shashtri S and Mukherjee S (2012a) Chemometric and GIS based analysis of geogenic augmentation of fluoride in groundwater of arid region of India International Journal of Environmental Protection 2 24-29

Singh C K, Shashtri S N, Kumari R and Mukherjee S (2012b) Chemometric analysis to infer hydro-geochemical processes in a semi-arid region of India Arabian Journal of Geosciences doi: 10.1007/s12517-012-0597-3

Singh C K, Rina K, Singh R P, Shashtri S, Kamal V and Mukherjee S (2011) Geochemical modeling of high fluoride concentration in groundwater of Pokhran area of Rajasthan, India Bull Environ ContamToxicol 86 152-158 doi: 10.1007/ s00128-011-0192-4

Singh S K, Ghosh A K, Kumar A, Kislay K, Kumar C, Tiwari R R, Parwez R, Kumar N and Imam M D (2014) Groundwater arsenic contamination and associated health risks in Bihar, India Int $J$ Environ Res 8 49-60 Winter. ISSN: 1735-6865

Singh S K and Ghosh A(2011) Entry of arsenic into food materialA case study World Applied Sciences Journal 13 385-390 2011: ISSN 1818-4952 _ IDOSI Publications, 2011. Available athttp://idosi.org/wasj/wasj13(2)/30.pdf (Assessed 27 June 2016)

Singh I B (1996) Geological evolution of Ganga Plain an overview Journal of The Palaeontological Society of India 4199137

Sinha R, Yadav G S, Gupta S, Singh A and Lahiri S K (2013) Geoelectric resistivity evidence for subsurface palaeochannel systems adjacent to Harappan sites in northwest India Quaternary International 308-309 66-75 doi: org/10.1016/ j.quaint.2012.08.002

Sinha R, Kettanah Y, Gibling M R, Tandon S K, Jain M, Bhattacharjee P S, Dasgupta A S and Ghazanfari P (2009) Craton - derived alluvium as a major sediment source in the Himalayan Foreland Basin of India GSA Bulletin 121
$1596-1610$

Srinivasamoorthy K, Vijayaraghavan K, Vasanthavigar M, Sarma S, Chidambaram S, Anandhan P and Manivannan R (2010) Assessment of groundwater quality with special emphasis on fluoride contamination in crystalline bed rock aquifers of Mettur region, Tamilnadu, India Arab J Geosci doi: 10.1007/s12517-010-0162-x

Sivasubramanian P, Balasubramanian N, Soundranayagam J P and Chandrasekar N (2013) Hydrochemical characteristics of coastal aquifers of Kadaladi, Ramanathapuram District, Tamilnadu, India Appl Water Sci doi: 10.1007/s13201-0130108-z

Soni V, Shekhar S and Singh D (2014) Environmental flow for the Yamuna river in Delhi as an example of monsoon rivers in India Curr Sci 106 558-564

Sonkamble S, Chandra S, Nagaiah E, Dar FA, Somvanshi V K and Ahmed S (2014) Geophysical signatures resolving hydrogeological complexities over hard rock terrain-a study from Southern India Arab J Geosci doi: 10.1007/ s12517-013-0931-4

Sonkamble S, Sahya A, Mondal N C and Harikumar P (2012). Appraisal and evolution of hydrochemical processes from proximity basalt and granite areas of Deccan Volcanic Province (DVP) in India Journal of Hydrology 438-439 181-193 doi.org/10.1016/j.jhydrol.2012.03.022

Srivastava P K, Singh S K, Gupta M, Thakur J K and Mukherjee S (2014) Modeling impact of landuse change trajectories on groundwater quality using remote sensing and GIS Environmental Engineering and Management Journal 12 2013

Thivya C, Chidambaram S, Tirumalesh K, Prasanna M V, Thilagavathi R, Adithya V S and Singaraja C (2016) Lithological and Hydrochemical controls on distribution and speciation of uranium in groundwaters of hard-rock granitic aquifers of Madurai district, Tamil Nadu (India) Environ Geochem Health doi: 10.1007/s10653-015-97357

Tiwari V M, Wahr J and Swenson S (2009) Dwindling groundwater resources in northern India, from satellite gravity observations Geophys Res Lett 36 L18401 doi: 10.1029/2009GL039401

Van Dijk W M, Desmore A S, Singh A, Gupta S, Sinha R, Mason P J, Joshi S K, Nayak N, Kumar M, Shekhar S, Kumar D and Rai S P (2016) Linking the morphology of fluvial fan systems to aquifer stratigraphy in the Sutlej-Yamuna plain of northwest India J Geophys Res Earth Surf 121 201-222 doi: 10.1002/2015JF003720

Varade A M, Khare Y D, Mondal N C, Muley S, Wankawar P and 
Raut P (2012) Identification of Water Conservation Sites in a Watershed (WRJ-2) of Nagpur District, Maharashtra using Geographical Information System (GIS) Technique J Indian Soc Remote Sens 41 619-630 doi: 10.1007/s12524012-0232-5. pp. 619-630

Vittala S S, Reddy G R C and Najeeb K M (2013) Data Gap Analysis for Ground Water Surveys: A Case Study J Geol Soc India 82 440-441
Yogeshwar P, Tezkan B, Israil M and Candansayar M E (2012) Groundwater contamination in the Roorkee area, India: $2 \mathrm{D}$ joint inversion of radiomagnetotelluric and direct current resistivity data Journal of Applied Geophysics 76 127-135 doi: org/10.1016/j.jappgeo.2011.11.001. 